\title{
Pengaruh Tipe Kepribadian, Beban Kerja, dan Gaya Kepemimpinan terhadap Stres Kerja Karyawan BRI Cabang Pasaman Barat
}

\author{
Filiani Qarisa Maulina, Hendra Lukito \\ Jurusan Manajemen, Fakultas Ekonomi, Universitas Andalas
}

\begin{abstract}
ABSTRAK
Peneltian ini bertujuan untuk menguji pengaruh Tipe Kepribadian, Beban Kerja, dan Gaya Kepemimpinan terhadap Stres Kerja pada karyawan BRI Cabang Pasaman Barat. Pendekatan dalam penelitian ini adalah pendekatan kuantitatif yang digunakan untuk menjelaskan hubungan antar variable penelitian. Data dalam penelitian ini adalah data primer yang berasal dari jawaban responden melalui kuisioner yang disebarkan kepada responden. Populasi dan sampel dalam penelitian ini berjumlah 94 orang dengan metode pengambilan sampel secara sensus. Metode pengolahan data dilakukan dengan program SPSS dan pengujian hipotesis dilakukan dengan uji $\mathrm{t}$. Hasil penelitian menunjukkan bahwa kepribadian ekstrovert berpengaruh negatif dan signifikan terhadap stres kerja, kepribadian introvert berpengaruh positif dan signifikan terhadap stres kerja, beban kerja berpengaruh positif dan signifikan terhadap stres kerja, dan gaya kepemimpinan berpengaruh negatif dan signifikan terhadap stres kerja.
\end{abstract}

Keywords: kepribadian ekstrovert, kepribadian introvert, beban kerja, gaya kepemimpinan, stres kerja

\section{Pendahuluan}

Kekuatan lingkungan seperti lingkungan ekonomi, politik, teknologi, dan sosial budaya yang terus berkembang dengan cepat membuat organisasi harus senantiasa siaga dan cepat tanggap untuk merespon dan mengantisipasi setiap perubahan dan perkembangan zaman yang terjadi. Hal ini membawa pengaruh pada lingkungan perusahaan, perusahaan dan juga karyawan. Persaingan yang semakin ketat dalam dunia perbankan dengan banyaknya kompetitor membawa arus persaingan yang tidak lagi hanya pada price competition dan bunga, melainkan juga pada non-price competition. Persaingan dalam kualitas ini akan menuju pada Good Corporate Governance (GCG). Ditengah kondisi tersebut, setiap industri dituntut untuk dapat meningkatkan daya saingnya dalam segala aspek termasuk sumber daya manusianya.

Sumber daya manusia termasuk faktor penting dalam meningkatkan kualitas yang dimiliki oleh perusahaan. Oleh karena itu, agar perusahaan bias berkembang secara optimal, maka pemeliharaan hubungan yang kontinyu dan serasi dengan para karyawan menjadi sangat penting. Salah satu hal yang harus diperhatikan dalam pemeliharaan hubungan tersebut adalah mengenai penanggulangan stres para karyawan. Stres yang tidak diatasi dengan baik akan berakibat pada ketidakmampuan seseorang berinteraksi secara positif dengan lingkungannya, baik lingkungan pekerjaan maupun di luar pekerjaan. Mengingat besarnya pengaruh stres pada karyawan terhadap kinerjanya, pengelolaan terhadap stres itu sendiri harus mendapatkan perhatian dari manajemen perusahaan agar tujuan organisasi lebih mudah dicapai.

Salah satu faktor yang mempengaruhi munculnya stres kerja adalah kepribadian (Robbins, 2008). Menurut Feist dan Feist (2006), secara umum kepribadian (personality) adalah satu pola watak (traits) yang relatif permanen, dan sebuah karakter unik yang memberikan konsistensi bagi perilaku seseorang. Robbins dan Judge (2009) mendefinisikan kepribadian sebagai organisasi dinamis dalam sistem psikologis individu yang menentukan caranya untuk menyesuaikan diri 
secara unik terhadap lingkungannya. Oleh karena itu kepribadian bisa menjadi salah satu faktor bagaimana individu menyesuaikan diri terhadap lingkungannya, dan bagaimana individu menangani stres yang dialaminya yang disebabkan oleh pekerjaan, setiap tipe kepribadian memiliki caranya sendiri untuk menangani hal tersebut.

Karyawan juga sering dihadapkan kepada berbagi masalah di perusahaan, sehingga sangat mungkin akan mengalami stres. Luthan (2008) menyatakan bahwa stres bukanlah sekedar ketegangan syaraf, stres dapat memiliki konsekuensi yang positif, stres bukanlah sesuatu yang harus dihindari, dan tidak adanya stres sama sekali adalah kematian. Pekerjaan yang diberikan perusahaan kepada karyawan dapat menimbulkan stres kerja. Apabila pekerjaan tersebut melebihi batas kemampuan maka akan timbul suatu tekanan yang dirasakan karyawan, hal tersebut dapat memicu terjadinya stres kerja. Sehingga beban kerja mempunyai pengaruh terjadap stres kerja.

Faktor lain yang sangat berkaitan dengan stres adalah gaya kepemimpinan (Harms et al., 2016). Pemimpin memiliki peranan yang sangat penting pada praktik kerja sehari-hari. Kepemimpinan yang tidak terintegrasi dengan harapan pegawai seperti memberikan tuntutan yang terus-menerus dapat menimbulkan dampak negatif bagi kesehatan pegawai (Bradley, 2015). Oleh karena itu tekanan yang diberikan oleh pimpinan akan berpengaruh pada kesehatan mental yang bisa mengakibatkan stress terhadap karyawan.

PT. Bank Rakyat Indonesia (Persero) merupakan industri perbankan yang memiliki sumber daya manusia sebagai asset penting dalam menjalankan fungsinya. Dalam kegiatannya bank BRI memiliki target bagi setiap karyawannya yang menyebabkan karyawannya memiliki tuntutan kerja yang berat dan harus diselesaikan tepat waktu. Target yamg diberikan harus diselesaikan oleh karyawan setiap bulannya dan kondisi ini berdampak kepada munculnya stres, sehingga tipe kepribadian, beban kerja, dan gaya kepemimpinan bisa mempengaruhi stres karyawan ditengah segala perubahan dan tekanan yang harus dipikul oleh karyawan tersebut.

Tabel 1

Target RKA Bank BRI Cabang Pasaman Barat Periode Juli - Desember 2019

\begin{tabular}{|l|l|r|r|r|r|r|r|}
\hline \multirow{2}{*}{\multicolumn{2}{|c|}{ Keterangan }} & \multicolumn{6}{|c|}{ Target Rencana Kerja Anggaran 2019 } \\
\cline { 2 - 8 } & Juli & Agustus & September & Oktober & November & Desember \\
\hline A. & Tabungan (orang) & 99.434 & 95.459 & 92.358 & 93.903 & 95.706 & 97.785 \\
\hline B. & Debitur mikro (Orang) & 15.540 & 15.629 & 15.718 & 15.808 & 15.897 & 15.986 \\
\hline C. & Debitur kecil (orang) & 583 & 589 & 596 & 603 & 610 & 615 \\
\hline D. & Debitur ritel (orang) & 48 & 49 & 50 & 51 & 52 & 55 \\
\hline E. & $\begin{array}{l}\text { Debitur konsumen } \\
\text { (orang) }\end{array}$ & 977 & 978 & 979 & 980 & 981 & 981 \\
\hline F. & Deposito (orang) & 9.318 & 9.277 & 9.239 & 9.213 & 9.741 & 10.344 \\
\hline
\end{tabular}

Sumber: Data BRI Cabang Pasaman Barat, 2019

Berdasarkan tabel diatas dapat dilihat jumlah nasabah yang dilayani oleh BRI cabang Pasaman Barat dengan beberapa pengelompokan nasabah berdasarkan kategori yang ditetapkan oleh perusahaan yaitu: tabungan, debitur mikro, ritel, konsumen, dan deposito. Data tersebut juga menunjukkan nasabah yang menjadi target pelayanan perusahaan yang harus dicapai setiap bulannya, disamping itu karyawan juga dituntut untuk cepat beradaptasi akan perubahan baik sistem maupun non sistem. Seperti yang diketahui, saat ini di era digitalisasi Bank BRI banyak mempergunakan sistem yang terkomputerisasi untuk membuat pekerjaan lebih mudah dimana penggunaan ini memiliki dampak positif dan negatif terhadap karyawan. Dampak positifnya 
adalah pekerjaan karyawan akan sangat terbantu oleh sistem ini sedangkan dampak negatifnya karyawan diminta untuk cepat paham dan mengerti dalam mengoperasikan sistem ini sehingga dapat menggunakannya dengan benar. Hal ini dilakukan untuk meningkatkan kualitas pelayanan dalam rangka mengatasi persaingan yang semakin ketat dewasa ini. Karyawan yang dituntut untuk beradaptasi dan mempelajari sistem yang baru untuk mencapai target yang telah ditetapkan dengan aturan yang baru tidaklah mudah. Kondisi yang seperti ini akan menyebabkan banyaknya karyawan yang merasa tertekan dalam pekerjaannya yang pada akhirnya akan menyebabkan munculnya stress.

Berdasarkan latar belakang yang telah diuraikan, maka perumusan masalah pada penelitian ini adalah:

1. Bagaimanakah pengaruh tipe kepribadian terhadap stres kerja karyawan BRI cabang Pasaman Barat?

2. Bagaimanakah pengaruh beban kerja terhadap stres kerja karyawan BRI cabang Pasaman Barat?

3. Bagaimanakah pengaruh kepemimpinan terhadap stress kerja karyawan BRI cabang Pasaman Barat?

\section{Literatur Review}

\section{Stres Kerja}

Stres kerja merupakan suatu tanggapan dari lingkungan luar yang dianggap berlebihan oleh individu kaerna hal tersebut diluar batas kemampuannya (Luthans, 2005; Gibson et al. 2012; Fahmi, 2013). Luthans (2005) menyatakan bahwa dampak positif yang ditimbulkan oleh stres kerja dapat meningkatkan kinerja. Sedangkan perubahan perilaku individu yang akan menurunkan kerjasama antar pegawai pada suatu organisasi merupakan dampak negatif dari stres. Alat ukur dari stres kerja menurut Enshassi et al. (2015) yakni:

1. stres kerja yang disebabkan oleh organisasi (gaji, jumlah pegawai, komunikasi)

2. stres kerja yang disebabkan oleh tugas (durasi bekerja, beban kerja, ambiguitas peran)

3. stres kerja yang disebabkan oleh individu (dukungan dari pimpinan, dukungan hubungan antar rekan kerja)

4. stres kerja yang disebabkan oleh lingkungan kerja sekitar, seperti: kenyamanan lingkungan kerja, pencahayaan, keamanan lingkungan kerja.

\section{Kepribadian}

Menurut Robbins dan Judge (2009) kepribadian terbagi menjadi dua tipe yaitu kepribadian tipe A dan kepribadian tipe B. Secara garis besar tipe kepribadian A dijelaskan sebagai kepribadian yang memiliki ciri ambisius, selalu menuntut kesempurnaan sehingga tidak dapat mengatasi waktu untuk bersantai, tipe kepribadian ini memiliki kecenderungan untuk mengalami tingkat stres yang lebih tinggi, sebab menempatkan diri sendiri pada suatu tekanan waktu dengan menciptakan suatu batas waktu tertentu untuk kehidupan. Sedangkan tipe kepribadian B adalah kebalikannya tipe kepribadian A.

Kepribadian tipe A berpengaruh positif dan signifikan terhadap stres dan B berpengaruh negatif dan signifikan terhadap stres kerja. Secara umum pribadi yang ekstrover mendapatkan gairah atau energi dari interaksi sosial. Ekstrover biasanya memiliki kepribadian yang terbuka dan senang bergaul, serta memiliki kepedulian yang tinggi terhadap apa yang terjadi di sekitarnya. Sementara introver, di sisi lain, dianggap mendapatkan gairah lewat menyendiri. Introver biasanya 
cenderung pendiam, suka merenung, dan lebih peduli tentang pemikiran dalam dunianya sendiri. Di antara kecenderungan ekstrem introversi dan ekstroversi, terdapat ambiversi yang merupakan kepribadian penengah antara ekstrover dan introver.

Menurut Boeree (2009), indikator yang mempengaruhi dalam kepribadian ini adalah sebagai berikut:

1. Activity, yaitu yang berkaitan dengan faktor aktivitas.

2. Sociability, yaitu kemampuan bermasyarakat.

3. Risk taking, yaitu pengambilan resiko.

4. Impulsiveness, yaitu memperturutkan suara hati.

5. Expressiveness, yaitu kemampuan untuk menyatakan atau mengungkapkan perasaanperasaan cinta, benci, sedih, marah, atau takut secara terbuka dan dapat diamati.

6. Reflectiveness, yaitu memikirkan atau membayangkan.

7. Responsibility, yaitu tanggung jawab.

\section{Beban Kerja}

Menurut Dhania (2010), pengertian beban kerja adalah sekumpulan atau sejumlah kegiatan yang harus diselesaikan oleh suatu unit organisasi atau pemegang jabatan dalam jangka waktu tertentu. Mansour dan Tremblay (2015) dengan menggunakan skala ukur Job Content Questionnaire (JCQ). JCQ merupakan alat untuk mengukur karakter psikologis dari pekerjaan, yaitu:

1. Tuntutan psikologi yaitu suatu keadaan ketidakseimbangan antara presepsi individu terhadap tuntutan atas diri sendiri (yang berhubungan dengan pekerjaan) dan kemampuannya untuk mengatasi tuntutan-tuntutan tersebut.

2. Ambiguitas peran yaitu ketika karyawan tidak mempunyai informasi atau pengetahuan yang cukup jelas untuk melaksanakan suatu pekerjaan atau tugas.

3. Konsentrasi yaitu sumber kekuatan pikiran dan bekerja berdasarkan daya ingat dan lupa dimana pikiran tidak dapat bekerja untuk lupa dan ingat dalam waktu yang bersamaan.

4. Gangguan mental kerja yaitu suasana hati atau perasaan yang diterima seseorang yang terus tertekan atau kehilangan minat dalam beraktivitas.

\section{Gaya Kepemimpinan}

Kepemimpinan dapat dijelaskan sebagai proses interaksi antara pemimpin dan karyawan, dimana pemimpin berusaha untuk mempengaruhi karyawan untuk memenuhi tujuan bersama. Tentunya, setiap pimpinan menerapkan gaya kepemimpinannya sendiri. Kepemimpinan merupakan suatu proses yang dilakukan untuk mempengaruhi orang lain guna mencapai hasil yang diharapkan organisasi (Armstrong, 2009; Moorhead dan Griffin, 2013).

Alat ukur untuk gaya kepemimpinan yang dinyatakan oleh Famakin dan Abisuga (2016) adalah:

a. Mengarahkan (directive), tipe ini sama dengan model kepemimpinan otokratis dari Lippit and White. Pengarahan dalam pelaksanaan tugas berasal dari pemimpin, dalam model ini tidak ada pertisipasi dari bawahan

b. Mendukung (supportive), kepemimpinan model ini mempunyai kesedian untuk menjelaskan sendiri, bersahabat, mudah didekati, dan mempunyai perhatian kemanusiaan yang murni terhadap bawahannya.

c. Partisipatif (participative), gaya kepemimpinan ini pemimpin berusaha meminta dan mempergunakan saran-saran dari bawahannya. Namun pengambilan keputusan tetap berada padanya. 
d. Orientasi yang bertugas pada pencapaian (achievement oriented), gaya kepemimpinan ini menetapkan serangkaian tujuan yang menantang para bawahannya untuk berpartisipasi. Demikian pula pemimpin memberikan keyakinan kepada mereka bahwa mereka.

\section{Kerangka Konseptual Penelitian}

Berdasarkan pembahasan pada bagian sebelumnya maka kerangka konseptual dalam penelitian ini adalah seperti dijelaskan dalam gambar berikut.

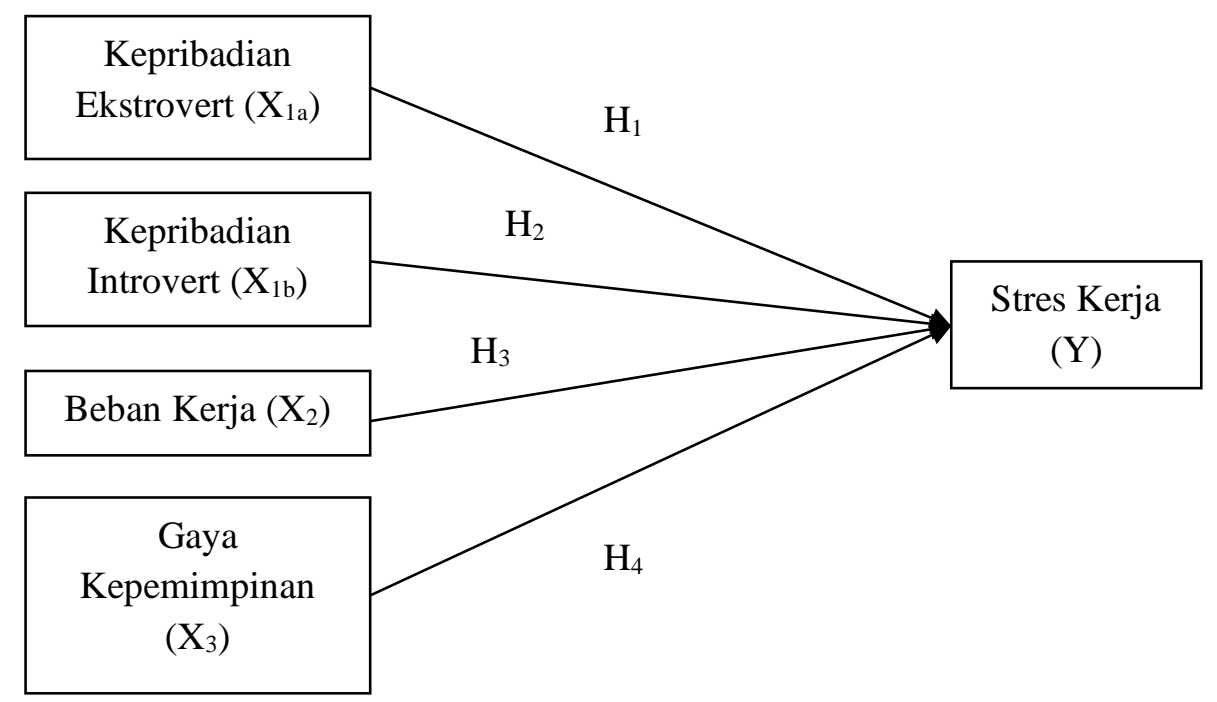

Gambar 1 Kerangka Konseptual Penelitian

Kerangka diatas menggambarkan tujuan penelitian dan hipotesis yang akan diuji dalam penelitian ini. Tujuan dari penelitian ini adalah untuk mengetahui pengaruh dari kepribadian (ekstrovert dan introvert), beban kerja dan gaya kepemimpinan terhadap stres kerja karyawan BRI Cabang Pasaman Barat. Sedangkan hipotesis yang akan diuji dalam penelitian ini adalah:

1. $\mathrm{H}_{1 \mathrm{a}}$ : Kepribadian ekstrovert berpengaruh negatif dan signifikan terhadap stres kerja

2. $\mathrm{H}_{1 \mathrm{~b}}$ : Kepribadian intovert berpengaruh positif dan signifikan terhadap stres kerja

3. $\mathrm{H}_{2}$ : Beban kerja berpengaruh positif dan signifikan terhadap stres kerja

4. $\mathrm{H}_{3}$ : Gaya kepemimpinan berpengaruh negatif dan signifikan terhadap stres kerja

\section{Metode Penelitian}

\section{Desain Penelitian}

Penelitian ini menggunakan pendekatan kuantitatif melalui penelitian eksplanatory research yaitu suatu penelitian yang bertujuan untuk menguji hipotesis tentang hubungan antar variabel yang diteliti (Sekaran, 2011). Pendekatan ini bertujuan untuk memberikan gambaran yang jelas tentang pengaruh tipe kepribadian, beban kerja dan gaya kepemimpinan terhadap stres kerja pada karyawan BRI cabang Pasaman Barat. Data dalam penelitian ini diperoleh melalui data primer dengan menyebarkan kuesioner langsung dengan pengukuran variable menggunakan skala likert 1-5 kepada Karyawan BRI cabang Pasaman Barat yang kemudian data tersebut akan diolah menggunakan software statistik yaitu SPSS (Statistical Package for Social Science) versi 24.

\section{Populasi, Sampel dan Sampling}


Populasi dalam penelitian ini adalah seluruh karyawan BRI cabang Pasaman Barat yang berjumlah 128 orang. Sampel dalam penelitian ini berjumlah 128 orang dengan metode yang dipilih mewakili seluruh anggota populasi atau sampel yang digunakan adalah sampel jenuh atau sensus dimana jumlah sampel sama dengan jumlah populasi yaitu 128 orang karyawan BRI cabang Pasaman Barat.

\section{Metode Analisa Data}

\section{Uji Instrumen Penelitian}

Uji Validitas

Uji validitas digunakan untuk mengukur sah atau valid tidaknya suatu kuesioner. Suatu kuesioner dikatakan valid jika pertanyaan atau pernyataan pada kuesioner mampu untuk mengungkapkan sesuatu yang akan diukur oleh kuesioner tersebut (Sugiyono, 2012). Uji validitas instrumen dilakukan dengan bantuan software SPSS 24 dengan mengetahui nilai Corrected Item Total Correlation yang merupakan $r$ hitung yang dibandingkan dengan $r$ tabel. Suatu instrumen dikatakan valid apabila $r$ hitung lebih besar daripada $r$ tabel.

\section{Uji Reliabilitas}

Ghozali (2011) mendefenisikan reliabilitas adalah alat ukur untuk mengukur suatu kuesioner yang merupakan indikator dari suatu variabel atau konstruk, suatu kuesioner dapat dikatakan handal jika jawaban seseorang terhadap pertanyaan adalah konsisten atau stabil dari waktu ke waktu. Pengujian akan dilakukan dengan bantuan program SPSS 24 dengan mengetahui nilai Cronbach's Alpha yang akan menunjukkan koefisien reliabilitas dan nilai Cronbach's Alpha yang mendekati 1,00 maka semakin baik (Sekaran, 2011).

\section{Uji Asumsi Klasik \\ Uji Normalitas}

Sekaran (2011) mengemukakan uji normalitas pada model regresi digunakan untuk menguji apakah nilai residual terdistribusi secara normal atau tidak. Uji normalitas dalam penelitian ini dilakukan dengan analisis grafik (normal P-P plot), jika titik-titik menyebar sekitar garis dan mengikuti garis diagonal maka residual pada model regresi tersebut normal.

\section{Uji Multikolinearitas}

Pengujian ini bertujuan untuk menguji ada tidaknya korelasi antar variabel independen melalui nilai tolerance dan VIF. Jika nilai tolerance lebih besar dari 0,1 dan nilai VIF kecildari 10 maka dapat disimpulkan tidak terjadi multikolinearitas.

\section{Uji Heteroskedastisitas}

Uji heteroskedastisitas bertujuan untuk menguji apakah model regresi terjadi ketidaksamaan varian dari residual satu pengamatan ke pengamatan lain (Sekaran, 2011). Model regresi yang baik adalah model yang tidak terjadi heteroskedastisitas. Untuk mendeteksi ada tidaknya heteroskedastisitas pada suatu model dapat dilihat pada pola gambar Scatterplot model tersebut (Ghozali, 2011).

\section{Koefesien Determinan $\left(\mathbf{R}^{2}\right)$}

Koefesien determinan pada intinya mengukur seberapa jauh kemampuan sebuah model dalam menerangkan variasi variabel dependen. Nilai $\mathrm{R}^{\mathbf{2}}$ yang kecil mengartikan variasi variabel dependen 
yang sangat terbatas, dan nilai yang mendekati 1 (satu) mengartikan variabel-variabel independen sudah dapat memberi semua informasi yang dibutuhkan untuk memprediksi variabel dependen (Ghozali, 2009). Apabia nilai $\left(\mathrm{R}^{2}\right)$ kecil, maka variabel bebas hanya menjelaskan sedikit informasi dan terbatas tentang variabel terikat. Sebaliknya, jika nilai $\left(\mathrm{R}^{2}\right)$ besar maka variabel bebas dapat menjelaskan bahwa banyak informasi dan tidak terbatas tentang variabel terikat.

\section{Persamaan Regresi Linier Berganda}

Analisis data yang digunakan pada penelitian ini adalah analisis regresi linier berganda, yaitu suatu teknik statistik yang dipergunakan untuk mengetahui seberapa besar pengaruh variabel bebas terhadap variabel terikat (Sekaran, 2011). Analisis regresi berganda diguanakan untuk mengetahui pengaruh hubungan dari variabel-variabel independen dan dependen antara tipe kepribadian $\left(\mathrm{X}_{1}\right)$, Beban Kerja $\left(\mathrm{X}_{2}\right)$, Gaya Kepemimpinan $\left(\mathrm{X}_{3}\right)$ terhadap Stres Kerja (Y). Adapun persamaan yang digunakan dalam penelitian ini adalah:

Keterangan :

$$
Y=a+b_{1} X_{1 a}+b_{1 b} X_{1 b}+b_{2} X_{2}+b_{3} X_{3}+e
$$

$$
\begin{aligned}
& \mathrm{Y}=\text { Stres Kerja } \\
& \mathrm{a}=\text { Konstanta } \\
& \mathrm{b}=\text { Koefien regresi masing-masing variabel } \\
& \mathrm{X}_{1}=\text { Tipe Kepribadian } \\
& \mathrm{X}_{2}=\text { Beban Kerja } \\
& \mathrm{X}_{3}=\text { Gaya Kepemimpinan } \\
& \mathrm{e}=\text { Standart error }
\end{aligned}
$$

\section{Uji Hipotesis (Uji t)}

Uji statistik pada dasarnya menunjukkan pengaruh variabel independen secara individual terhadap variabel independen. Prosedur yang digunakan untuk melakukan uji t adalah sebagai berikut: jika didapatkan hasil pengujian bahwa t hitung lebih besar daripada tabel ataupun jika signifikansi lebih kecil dari 0,05 maka variabel independen memiliki pengaruh yang signifikan terhadap variabel dependen.

\section{Hasil dan Pembahasan}

\section{Uji Instrumen Penelitian}

\section{Uji Validitas}

Hasil uji validitas dalam penelitian ini menunjukkan bahwa dari 14 item pernyataan untuk variabel tipe kepribadian, 12 pernyataan untuk variabel beban kerja, 12 pernyataan untuk variabel gaya kepemimpinan, dan 12 pernyataan untuk variabel stres kerja yang diuji validitasnya dimana semua instrumen penelitian dinyatakan valid karena memiliki nilai $r$ hitung lebih besar dari 0,3 . Berdasarkan hasil tersebut maka semua item pernyataan dalam kuisioner dapat digunakan dalam pengolahan lebih lanjut.

\section{Uji Reliabilitas}

Uji reliabilitas yang dilakukan pada masing-masing variabel menunjukkan nilai cronbach's alpha diatas 0,6 sehingga dapat dikatakan semua konsep pengukur dari masing-masing variabel pada penelitian ini dapat dikatakan reliable dan dapat dilanjutkan untuk proses berikutnya. 


\section{Uji Asumsi Klasik}

\section{Uji Normalitas}

Uji normalitas dalam penelitian ini dengan menggunakan grafik P-P Plot menunjukkan bahwa data-data dalam penelitian ini tersebar disekitar garis diagonal dan menyebar disepanjang grafik histogramnya. Ini menunjukkan pola distribusi normal karena membentuk satu garis lurus diagonal dan ploting data akan dibandingkan dengan garis diagonal.

\section{Uji Multikolinearitas}

Hasil uji multikolinearitas untuk variabel independen pada penelitian menunjukkan tidak terjadinya korelasi antar variabel tipe kepribadian ekstrovert $\left(\mathrm{X}_{1 \mathrm{a}}\right)$, pada variabel tipe kepribadian introvert $\left(\mathrm{X}_{1 \mathrm{~b}}\right)$, pada variabel beban kerja $\left(\mathrm{X}_{2}\right)$, dan variabel gaya kepemimpinan $\left(\mathrm{X}_{3}\right)$. Semua variabel independen memiliki nilai tolerance lebih besar dari 0,1, sedangkan untuk nilai VIF semua variabel memiliki nilai yang kurang dari sepuluh. Informasi ini menunjukkan tidak adanya multikolineariras pada model regresi yang digunakan dalam penelitian ini.

\section{Uji Heteroskedastisitas}

Grafik scatterplot yang untuk uji heterokedastisitas pada penelitian ini memperlihatkan bahwa tidak terjadi heterokedastisitas, sebab tidak ada pola tertentu pada titik-titik yang menyebar baik di atas maupun di bawah angka 0 pada sumbu $\mathrm{Y}$ sehingga uji heterokedastisitas dapat dipenuhi.

\section{Koefesien Determinan $\left(\mathbf{R}^{2}\right)$}

Berdasarkan nilai adjusted $\mathrm{R}$ square dari pengolahan data yang dilakukan diperoleh nilai sebesar 0,411 yang artinya variabel independen dapat menjelaskan variabel dependen sebesar $41,1 \%$ dan sisanya sebesar $58,9 \%$ dijelaskan oleh variabel lain yang tidak dimasukkan dalam penelitian ini.

\section{Persamaan Regresi Linier Berganda}

Analisis data yang digunakan pada penelitian ini adalah analisis regresi linier berganda, dengan menggunakan program SPSS 24.0 dengan persamaan sebagai berikut:

$$
Y=3,295-0,235 X_{1 a}+0,287 X_{1 b}+0,297 X_{2}-0,328 X_{3}+e
$$

Keterangan :

$$
\begin{aligned}
& Y=\text { Stres Kerja } \\
& a=\text { Konstanta } Y \\
& b=\text { Koefien regresi masing-masing variabel } \\
& \text { X1a = Tipe kepribadian ekstrovert } \\
& \text { X1b= Tipe kepribadian introvert } \\
& X_{2}=\text { Beban Kerja } \\
& X_{3}=\text { Gaya Kepemimpinan } \\
& \text { e = Standart error }
\end{aligned}
$$

Persamaan regresi diatas dijelaskan sebagai berikut: 
a. Nilai a $=3,295$

Persamaan regresi diatas dapat diperoleh dengan penjelasan bahwa a (konstanta) = 3,295 menunjukkan besarnya nilai dari stres kerja $(\mathrm{Y})$. Jika variabel tipe kepribadian ekstrovert $\left(\mathrm{X}_{1 \mathrm{a}}\right)$, kepribadian introvert $\left(\mathrm{X}_{1 \mathrm{~b}}\right)$, beban kerja $\left(\mathrm{X}_{2}\right)$, dan gaya kepemimpinan $\left(\mathrm{X}_{3}\right)$ sama dengan nol atau konstan, maka stres kerja (Y) sama dengan 3,295.

b. Nilai $b_{1}=-0,235$

Koefisien regresi untuk kepribadian ekstrovert $\left(\mathrm{X}_{1}\right)$ bernilai negative $(-0,235)$ yang berarti terdapat hubungan negatif antara kepribadian ekstrovert dengan stress kerja (Y). Hal ini menjelaskan apabila seseorang memiliki kecendrungan semakin mendekati tipe kepribadian ekstrovert, maka stress kerja akan menurun dengan semua variabel tidak mengalami perubahan atau bersifat konstan.

c. Nilai $b_{2}=0,287$

Koefisien regresi untuk kepribadian introvert $\left(\mathrm{X}_{2}\right)$ bernilai positif $(0,287)$ yang berarti terdapat hubungan positif antara kepribadian introvert dengan stres kerja (Y). Hal ini menjelaskan apabila seseorang memiliki kecendrungan semakin mendekati kepribadian introvert maka stres kerja semakin meningkat dengan asusmsi semua variabel lain tidak mengalami perubahan atau bersifat konstan.

d. Nilai $b_{3}=0,297$

Koefisien regresi untuk kepribadian introvert $\left(\mathrm{X}_{2}\right)$ bernilai positif $(0,297)$ yang berarti terdapat hubungan positif antara beban kerja $\left(\mathrm{X}_{2}\right)$ dengan stress kerja $(\mathrm{Y})$. Hal ini menunjukkan bahwa apabila semakin meningkat beban kerja, maka stres kerja semakin meningkat pula dengan asumsi semua variabel lain tidak mengalami perubahan atau bersifat konstan.

e. Nilai $b_{4}=-0,328$

Koefisien regresi untuk gaya kepemimpinan bernilai negatif $(-0,328)$ yang berarti terdapat hubungan negatif antara gaya kepemimpinan $\left(\mathrm{X}_{3}\right)$ dengan stres kerja $(\mathrm{Y})$. Hal ini menjelaskan apabila semakin baik gaya kepemimpinan, maka stres kerja akan menurun dengan asumsi semua variabel lain tidak mengalami perubahan atau bersifat konstan.

\section{Uji Hipotesis (Uji t)}

Berikut adalah uji t dari hasil pengolahan data dengan menggunakan program SPSS 24.0 pada penelitian ini.

Tabel 2

\section{Hasil Uji Hipotesis}

\begin{tabular}{|c|l|c|c|c|}
\hline No & \multicolumn{1}{|c|}{ Variabel } & $\begin{array}{c}\text { t } \\
\text { hitung }\end{array}$ & Sig. & Keputusan \\
\hline 1. & Kepribadian Ekstrovert $\left(\mathrm{X}_{1 \mathrm{a}}\right)$ & -2.020 & 0,046 & Diterima \\
\hline 2. & Kepribadian Introvert $\left(\mathrm{X}_{1 \mathrm{~b}}\right)$ & 3,491 & 0,001 & Diterima \\
\hline 3. & Beban Kerja $\left(\mathrm{X}_{2}\right)$ & 2,970 & 0,004 & Diterima \\
\hline 4. & Gaya Kepemimpinan $\left(\mathrm{X}_{3}\right)$ & $-3,512$ & 0,001 & Diterima \\
\hline
\end{tabular}

Sumber: Hasil pengolahan data primer, 2019

Berdasarkan tabel diatas dapat dilihat bahwa hasil uji t untuk semua variabel kepribadian ekstrovert, kepribadian introvert, beban kerja, dan gaya kepemimpinan memiliki nilai sebagai berikut: untuk kepribadian ekstrovert memiliki nilai t-hitung $(-2,020)$ lebih besar dari t-tabel (1,99) dan nilai signifikansi $(0,046)$ lebih kecil dari 0,05 dimana hasil ini menunjukkan bahwa kepribadian ekstrovert berpengaruh negatif dan signifikan terhadap stres kerja. Kepribadian 
introvert memiliki nilai t-hitung $(3,491)$ lebih besar dari t-tabel $(1,99)$ dengan nilai signifikansi $(0,001)$ lebih kecil dari 0,05 hal ini menunjukkan bahwa variabel kepribadian introvert berpengaruh positif dan signifikan terhadap stres kerja. Beban kerja memiliki nilai t-hitung $(2,970)$ lebih besar dari t-tabel $(1,99)$ dengan nilai signifikansi $(0,004)$ lebih kecil dari 0,05 yang menunjukkan bahwa variabel beban kerja berpengaruh positif dan signifikan terhadap stres kerja. Gaya kepemimpinan memiliki nilai t-hitung $(-3,512)$ lebih besar dari t-tabel $(-1,99)$ dengan nilai signifikansi $(0,001)$ lebih kecil dari 0,05 yang menunjukkan bahwa gaya kepemimpinan berpengaruh negatif dan signifikan terhadap stres kerja.

\section{Kesimpulan}

Berdasarkan hasil penelitian tentang pengaruh tipe kepribadian, beban kerja, dan gaya kepemimpinan terhadap stres kerja pada karyawan BRI cabang Pasaman Barat, diperoleh kesimpulan sebagai berikut:

1. Kepribadian ekstrovert berpengaruh negatif dan signifikan terhadap stres kerja. Dari tujuh indikator variabel kepribadian yaitu activity, socialibility, risk tasking, impulsiveness, expressiveness, reflectiveness, responsibility, maka hasil yang diperoleh menunjukkan bahwa semakin memiliki kecendrungan perilaku sesuai dengan cirri-ciri kepribadian ekstrovert yang dikelompokkan oleh para ahli, maka semakin rendah stres kerja yang akan dialami oleh karyawan.

2. Kepribadian introvert berpengaruh positif dan signifikan terhadap stres kerja. Dari tujuh indikator variabel kepribadian yaitu activity, socialbility, risk tasking, impulsiveness, expressiveness, reflectiveness, responsibility, maka hasil yang diperoleh peneliti menunjukkan bahwa semakin memiliki kecendrungan perilaku sesuai dengan ciri-ciri kepribadian introvert yang dikelompokkan oleh para ahli, maka semakin tinggi stres kerja yang akan dialami oleh karyawan.

3. Beban kerja berpengaruh positif dan signifikan terhadap stres kerja. Dari empat indikator variabel beban kerja yaitu tuntutan psikologi, ambiguitas peran, konsentrasi, gangguan mental kerja, maka hasil yang diperoleh peneliti menunjukkan bahwa semakin tinggi beban kerja yang diemban oleh karyawan, maka semakin tinggi stres kerja yang akan dialami oleh karyawan tersebut.

4. Gaya kepemimpinan berpengaruh negatif dan signifikan terhadap stres kerja. Dari empat indikator variabel gaya kepemimpinan yaitu directive, supportive, participative, achievement oriented, maka hasil yang diperoleh peneliti menunjukkan bahwa semakin baik gaya kepemimpinan yang diterapkan oleh pimpinan, maka semakin rendah stres kerja yang akan dialami oleh karyawan tersebut.

\section{Implikasi}

Berikut merupakan beberapa implikasi penting dari hasil penelitian ini:

1. Kepribadian ekstrovert adalah kepribadian yang identik dengan mudah bersosialisasi terhadap lingkungannya. Hasil penelitian ini menunjukkan bahwa kepribadian ekstrovert berpengaruh negatif dan signifikan terhadap stres kerja. Hal ini memberikan implikasi bahwa perusahaan perlu menangani permasalahan karyawan ditinjau dari kepribadiannya, agar masalah yang dihadapi karyawan dalam pekerjaan mendapatkan solusi yang tepat, sehingga memotivasi karyawan agar kinerja karyawan tersebut dapat meningkat.

2. Kepribadian introvert adalah kepribadian yang identik dengan individualis dan sulit untuk membuka diri kepada orang lain. Hasil penelitian ini menunjukkan bahwa kepribadian 
introvert berpengaruh positif dan signifikan terhadap stres kerja. Hal ini memberikan implikasi bahwa perusahaan harus melakukan observasi kepada karyawan agar dapat mengidentifikasi kepribadian karyawan, bisa dilakukan dengan berbagai cara, hal ini untuk memudahkan pengelolaan karyawan agar mengurangi stres karyawan tersebut dan dapat menangani stres karyawan sesuai dengan cara yang diharapkannya.

3. Beban kerja adalah kemampuan tubuh dalam menerima suatu pekerjaan. Hasil penelitian ini menunjukkan bahwa beban kerja berpengaruh positif dan signifikan terhadap stres kerja. Hal ini memberikan implikasi bahwa perusahaan harus dapat mengukur kemampuan karyawan agar tugas yang diberikan dapat dilakukan dengan baik dan tujuan perusahaan dapat tercapai.

4. Gaya kepemimpinan adalah suatu pola menyeluruh dari tindakan pemimpin dalam mempengaruhi bawahannya. Hasil penelitian ini menunjukkan bahwa gaya kepemimpinan berpengaruh negatif dan signifikan terhadap stres kerja. Hal ini memberikan implikasi bahwa perusahaan perlu mempertahankan penerapan gaya kepemimpinan directive, supportive, participative, achievement oriented terhadap bawahannya agar kinerja karyawan tersebut akan meningkat serta stres kerja dapat dihindarkan.

\section{Daftar Pustaka}

Badenhorst, G., George, E. \& Louw, D. (2008). Job satisfaction among urban secondary school teachers in Namibia. South African Journal of Education, 28:135-154.

Bradley, P. M. d. L., 2005. Investigating work: family policy aims and employee experiences. Employee Relations, 27(5), pp. 478-494.

Boeree,G.C.Personalitytheories.Diunduhdarihttp://www.ship.edu\%7Ecgboeree/perscontents.htm 1

Dhani, Dhini, Rama. 2010. Desember Pengaruh Stres Kerja, Beban Kerja Terhadap Kepuasan Kerja. Studi Pada Medical Representatif Di Kota Kudus. Jurnal Psikologi Universitas Muria Kudus, I(1):12

Enshassi, A., El-Rayyes, Y., \& Alkilani, S. (2015). Job stres, job burnout and safety performance in Palestinian construction industry. Journal of Financial Management of Property and Construction, 20(2), 170-187.

Fahmi, I. (2013). Perilaku Organisasi: Teori, Aplikasi dan Kasus. Bandung: Alfabeta.

Famakin, I. O., \& Abisuga, A. O. (2016). Effect of path-goal leadership styles on the commitment of employees on construction projects. Journal of Construction Management, 16,(1), 1-10.

Feist, Jess, Gregory, Feist (2006). Teori Kepribadian (buku ke-1). Jakarta: Salemba Humanika.

Feist, Jess, Gregory, Feist (2013). Teori Kepribadian (buku ke-2). Jakarta: Salemba Humanika.

Gibson, J.L., Ivancevich, J.M., Donnelly Jr., J.H., \& Konopaske, R. (2012). Organizations: Behavior, Structure, Processes, 14th edition. New York: McGraw-Hill.

Harms, P.D., Crede, M., Tynan, M., Leon, M., \& Jeung, W. (2016). Leadership and stress: A metaanalytic review. The Leadership Quarterly, 28, 178-194.

Luthans, F. (2006). Perilaku Organisasi. (Edisi ke-10). Yogyakarta: ANDI.

Moorhead, G., \& Griffin, R. W. (2013). Perilaku Organisasi: Manajemen Sumber Daya Manusia dan Organisasi. Jakarta: Salemba Empat.

Robbins, Stephen P. 2008. Perilaku Organisasi: Konsep, Kontroversi, Aplikasi. PT Prenhallindo: Jakarta.

Robbins, Steaphen,P. Timothy A.Judge. 2015. Perilaku Keorganisasian. Edisi 16. Salemba Empat. Jakarta Selatan. 
Sekaran, U. (2011). Research Methods for Business: Metode Penelitian Untuk Bisnis. Jakarta, Salemba Empat.

Sugiyono. (2012). Metode Penelitian Administrasi. Bandung, Alfabeta.

Sugiyono, 2011, Metode Penelitian Kuantitatif, Kualitatif dan R\&D Bandung CV. Alfabeta. 